\title{
ANALYSIS OF THE HYDRAULIC OIL TO DRIVE BAND SAWMILL
}

Transport and material handling is a sum of technological processes in the wood-processing industry. Hydraulic drives are one of the drive options used as a basic part of the transport - handling machines. Contamination control involves preventing contaminants from entering a hydraulic system and placing filters in strategic locations throughout the system to trap any contaminants to find their way into the fluid. But for critical equipment, a successful contamination control program must also include regular assessment of the hydraulic fluid cleanliness. It must be often done every two to six months or after every 500 or 1,000 hours of operation, depending on the equipment duty cycle, operating environment, and how critical it is to overall operation. Pressure forces in hydraulic drives are transferred to hydraulically-operated devices which also serve to lubricate the elements, displace and remove heat from the system. To increase the service life of hydraulic drives, hydraulic oil must meet individual physical characteristics. To ensure reliability, timely diagnosis of hydraulic oil is required. Some experts also recommend that fluid to be tested immediately after any maintenance event that exposes the hydraulic system to the external environment. This could occur when a hose or other component is replaced or fluid is added to the reservoir. Fluid replenishment can be particularly troublesome because new fluid is notorious for being dirty often from improper storage and handling practices. The article deals with the methodology of measuring the basic physical properties of hydraulic oil by the respective diagnostic devices directly on the hydraulic drive of the bend saw in the full operation of the machine. The methodology suggested enables making decisions for improvement of the hydraulic oil state.

Keywords: hydraulic oil; diagnostic; no-failure operation; band saw.

Introduction. Transportation and manipulation with material is an important part of almost every technological process in industry. Manufacturing process consists of multiple operations that follow one another, and connection between them secures transportation and manipulation technology. Transportation and manipulation with material is greatly affecting quality, economics and safety of work in individual branches of industry. Because of this, it is necessary to dedicate increased attention to this problem to ensure, that manufacturing process is most effective and safest as it could be. From the function perspective oil is used as lubricant most of the time (engines, gears) or as a element for transfer of energy, alternatively it has sealing, cooling or filtrating function (Hnilica \& Dado, 2012; Antalov, 2017). Mineral oils are applied in almost every industry. They are substances of petroleum origin formed by mixture of higher hydrocarbons with the addition of special substances (Hybská et al., 2017, 2018). In all cases it is possible to make us of changing quality of oil. Contamination is causing most of the malfunctions in hydraulics. (Balog et al., 2002; Graça et al., 2011)

Experiences of designers and users of hydraulic and lubrication systems confirmed the facts, that more than $85 \%$ of all malfunctions are a straight consequence of contamination (Štollmann, 2010).

Expenses caused by contamination are growing grad- ually and are causing:

- Losses in manufacturing (downtime)

- Expenses for changing damaged parts

- Frequent fluid change

- Expensive elimination of faults

- Raised expenses for maintenance

- Raised expenses for confusions (Krilek, \& Dobrotová, 2016).

Material and methods. For prolonging the lifespan of hydraulic system for driving a bandsaw is required to check quality and amount of water contained in oil. Measurement was made on carriage made by Dinaco VEL - 970 bandsaw Dinaco FIL - 1600. On hydraulic drive of bandsaw carriage were with portable diagnostic device icountOS monitored parametres of purity of hydraulic oil and amounts of water. Capacity of oil reservoir of hydraulic unit driving the bandsaw carriage is 130 litres. System is filled with hydraulic oil Telus 46 Schell HLP ISO VG 46.

Parker Hannifin's icountOS (Figure 2) is an oil laser monitoring device. This mineral oil or aviation fuel contamination detector is designed for use in demanding environments and therefore its packaging is made of highly resistant resin HPX. This Vortex valve allows pressure relieving without draining water, and the soft handle of the icountOS is designed with a view to its high durability, functionality and future customization capabilities.

\section{Інформація про авторів:}

Крілек Йозеф, PhD, доцент, завідувач кафедри. Email: jkrilek@gmail.com

Ковач Ян, PhD, доцент, віцедекан. Email: kovac@vsld.tuzvo.sk

Кувік Томаш, інжинер. Email: t.kuvik14@gmail.com

Добротова Люція, інжинер. Email: I.dobrotova@brcslovakia.sk

Цитування за ДСТУ: Крілек Й., Ковач Я., Кувік Т., Добротова Л. Analysis of the hydraulic oil to drive band sawmill. Науковий вісник НЛтУ України. 2019, т. 29, № 10. С. 89-92.

Citation APA: Krilek, J., Kovach, J., Kuvik, T., \& Dobrotova, L. (2019). Analysis of the hydraulic oil to drive band sawmill. Scientific Bulletin of UNFU, 29(10), 89-92. https://doi.org/10.36930/40291018 


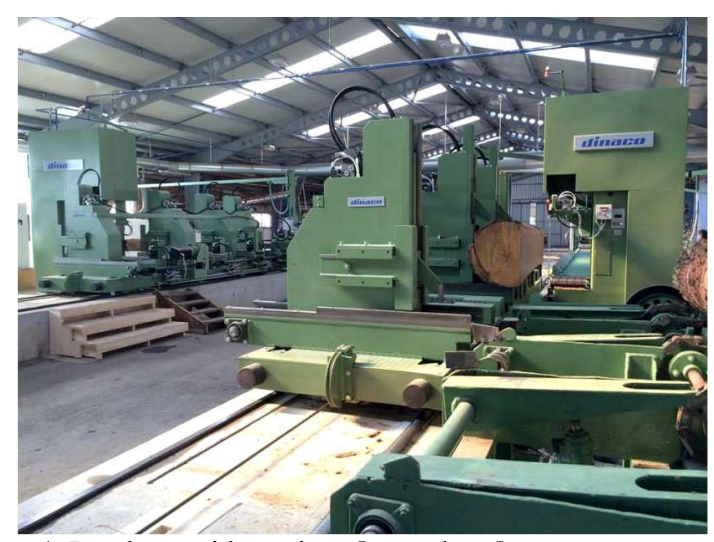

Figure 1. Bandsaw with carriage [own photo]

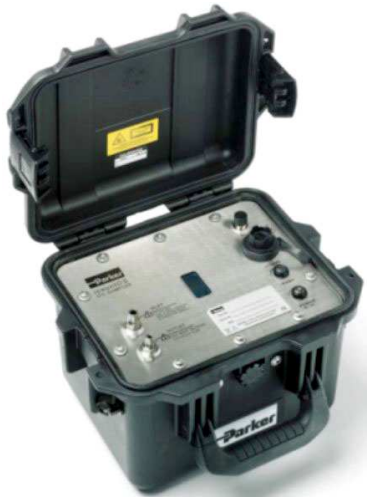

Figure 2. Parker Hannifin's icountOS monitoring device (icount Oil Sampler, 2011)

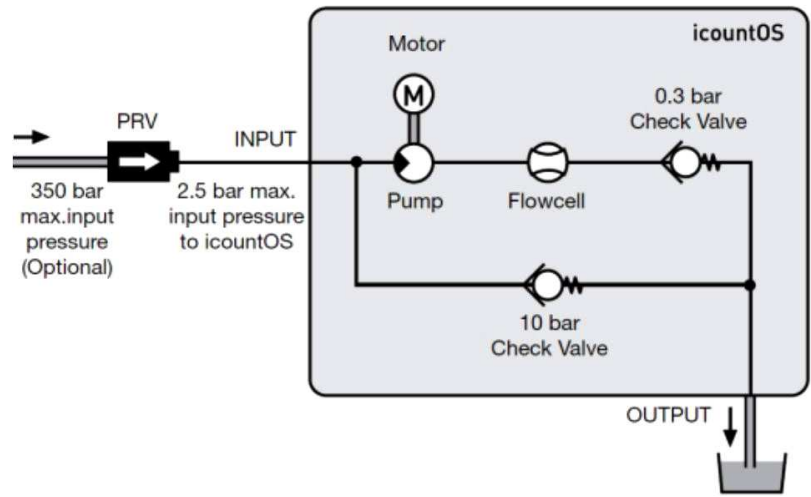

Figure 3. Hydraulic circuit icountOS (Icount Oil Sampler, 2011)

The measurement is carried out at the hydraulic oil operating temperature of the hydraulic saw blade carriage (Fithe low pressure hoses of the diagnostic tool are placed in the oil tank of the carriage and measured using the icountOS diagnostic device (Figure 3).

Results and discussion. The monitored parameters influence the lifetime of individual parts of the hydraulic system (distributor, pump, hydromotor,...). For this research, the unit was set according to ISO 4406: 1999 (Figure 4).

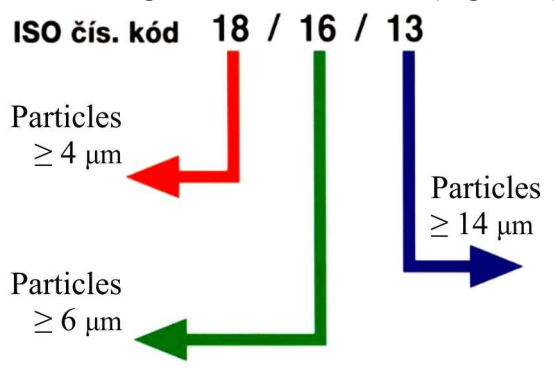

Figure 4. Description ISO 4406 of number code (Příručka filtrační techniky, 2015) gure 1) in order to mix the oil sufficiently. Subsequently,

In order to determine the state and its improvement (correction), the relative degree of pollution is used. Reading particle pollutants is the most common method for deriving a standard of purity. Very sensitive optical instruments are used to determine the number of particles of impurities in variable ranges associated with particle size. These values are then referred to as a number (count) of particles larger than a certain (determined) size that has been found in a given volume of liquid. The code number is assigned separately for each size category, and the resulting purity code corresponds to the worst code mark from each particle size (Dálik, 2011).

After 200 hours of operation, the measured values were ISO $17 / 15 / 13$ (Table 2 ) and $\%$ relative humidity $40 \%$, which is $120 \mathrm{ppm}$. It follows from the code number that particles of $4 \mu \mathrm{m}$ are found in $1 \mathrm{ml}$ of oil $640-1300$. The 6 $\mu \mathrm{m}$ particles are in $160 \mathrm{ml}$ of oil in $1 \mathrm{ml}$ of oil, and $14 \mu \mathrm{m}$ in $1 \mathrm{ml}$ of oil is $40-80$.

After 400 operating hours, ISO 18/16/13 and \% relative humidity of water were measured at $45 \%$ (Table 2 ), which is $135 \mathrm{ppm}$. The particle sizes of $4 \mu \mathrm{m}$ are in the $1 \mathrm{ml}$ of oil $1300-2500,6 \mu \mathrm{m}$ particles are in $320 \mathrm{ml}$ of oil in $1 \mathrm{ml}$ of oil, and $14 \mu \mathrm{m}$ particles are in $40 \mathrm{ml}$ of $1 \mathrm{ml}$ of oil (Table 1).

After 600 operating hours, ISO 19/17/14 and \% relative humidity $46 \%$ (Table 2 ) were measured, i.e. $138 \mathrm{ppm}$. A particle size of $4 \mu \mathrm{m}$ is present in $1 \mathrm{ml}$ of oil in the range of $2500-5000,6 \mu \mathrm{m}$ particles in $6 \mathrm{ml}$ of oil are $640-1300$, and $14 \mu \mathrm{m}$ particles in $1 \mathrm{ml}$ of oil are 80-160 (Table 1 ).

After 800 operating hours, ISO $21 / 20 / 20$ and \% relative water humidity $47 \%$ (Table 2 ) were measured, ie $141 \mathrm{ppm}$. A particle size of $4 \mu \mathrm{m}$ is present in $1 \mathrm{ml}$ of oil in the range of 10000-20000, $6 \mu \mathrm{m}$ particles in $5 \mathrm{ml}$ of oil are 5000 10000 , and particles of $14 \mu \mathrm{m}$ in $1 \mathrm{ml}$ of oil are 5000 10000 (Table 1).

Table 1. Table of measurements ISO 4406:1999 (Př́ručka filtrační techniky, 2015)

\begin{tabular}{|c|c|c|}
\hline \multicolumn{3}{|c|}{ ISO 4406:1999 table of measurements } \\
\hline \multirow{2}{*}{ Code number } & \multicolumn{2}{|c|}{ Particle count per ml } \\
\hline & More than & Up to, including \\
\hline 24 & 80,000 & 160,000 \\
\hline 23 & 40,000 & 80,000 \\
\hline 22 & 20,000 & 40,000 \\
\hline 21 & 10,000 & 20,000 \\
\hline 20 & 5,000 & 10,000 \\
\hline 19 & 2,500 & 5,000 \\
\hline 18 & 1,300 & 2,500 \\
\hline 17 & 640 & 1,300 \\
\hline 16 & 320 & 640 \\
\hline 15 & 160 & 320 \\
\hline 14 & 80 & 160 \\
\hline 13 & 40 & 80 \\
\hline 12 & 20 & 40 \\
\hline 11 & 10 & 20 \\
\hline 10 & 5 & 10 \\
\hline 9 & 2,5 & 5 \\
\hline 8 & 1,3 & 2,5 \\
\hline 7 & 0,64 & 1,3 \\
\hline 6 & 0,32 & 0,64 \\
\hline
\end{tabular}

Table 2. Table of measurements

\begin{tabular}{|c|c|c|}
\hline n. & ISO code & \% relative humidity water \\
\hline 1 & $17 / 15 / 13$ & 40 \\
\hline 2 & $18 / 16 / 13$ & 45 \\
\hline 3 & $19 / 17 / 14$ & 46 \\
\hline 4 & $21 / 20 / 20$ & 47 \\
\hline
\end{tabular}


Tribotechnical diagnostics is part of a non-disassemble technique for detecting the technical state of friction nodes based on a sample of the lubricant that they are lubricated (Kučera, 2000, 2003). Its task is to determine the status, evaluate and report the presence of foreign substances in the lubricant and its change, in quantitative and qualitative terms. Tribotechnical diagnostics enables us to rationally and economically use lubricants, early identification of emerging failures in the operation of machinery and equipment (Hnilicova \& Kučera, 2013, Hnilica \& Dado, 2012).

The method of detecting and determining the number of mechanical impurities is one of the most frequently used in operation, as it is economically and temporally least demanding and sufficiently precise (Graça et al., 2011).

The question remains what needs to be analyzed, because the parameters for the evaluation are fairly good. Authors Hnilic \& Kučera, 2013 provide a broader view of the methods used for hydraulic oil analysis.

Hydraulic oils are included in the group of industrial oils in which the water content should not exceed 500 ppm $(0.05 \%)$. The recommended maximum water content limit should be 200 ppm (0.02 \%) (Nováček, 2011; Př́ručka filtrační techniky, 2015). From the measured values it follows that relative to the $\%$ relative humidity of water is oil usable for hydraulic systems. This is bound water, which can be up to $300 \mathrm{ppm}$ in the hydraulic oil under consideration, and more than $300 \mathrm{ppm}$ already forms free water which forms an emulsion with the oil. For hydraulic systems, the permitted water content is up to $200 \mathrm{ppm}$. Above this value, oil may damage the hydraulic system such as corrosion.

It is necessary to perform regular diagnostics and filtration of oil fillings, as confirmed by the research of the authors Ilčík et al. (2011), Fitch and Troyer (2011), where $85 \%$ of hydraulic system failures arise due to contamination of hydraulic oil (Štollmann, 2010; Krilek et al., 2016; Day \& Bauer, 2007; Antalov, 2017).

Conclusion. From the measured ISO clarity values, an increasing tendency for impurities can be observed. This can be influenced by several factors. One of them is that the machine works in the dusty environment of the woodworking industry. Here, it is important to ensure that the elements are sufficiently sealed and that they do not get into the system through the leakage of dirt from the outside environment. Impurities from the outside can generate additional impurities in the system. They can cause single channel drainage in the valves, valve faults, failure of individual elements, poor system function, high failure, frequent machine downtime. This prevents predictive machine maintenance by monitoring oil contamination. First of all, filling the system with hydraulic oil by means of filtering devices, since hydraulic oil from drums is not of sufficient purity. Choice of appropriate filtering built into the system, and regular replacement of filter inserts. Clogged filter inserts cause great pressure losses in the system, as the hydraulic oil flows through them worse. Use filters with filter pointers to keep the machine maintenance when changing the filter cartridge.

In the case of woodworking machines, and not only, neglect of oil care leads to significant economic loss caused by long delays due to failure in hydraulic equipment. Therefore there is no need to make inexpensive compromises that will ultimately cost us, but we need to invest in quality filtration. This investment will later reflect on reducing the cost of spare parts, service, time consumption, breakdowns due to failures. Use fine air filters to filter aeration tanks of aggregates. Carefully select pressure or return filters, filters on separate filter branches. Take care of filter maintenance, replace filter inserts regularly and especially in time. Fill the hydraulic systems only with a filtering device, which can also be used as off-line filtering. By such measures we extend the life of not only hydraulic oil but also the hydraulic system itself.

Acknowledgment. The paper was written within the VEGA project no. 1/0826/15 "Research of cutting mechanisms in the processing wood materials".

\section{References}

Antalov, T. (2017). Diagnostika hydraulických olejov v dopravnomanipulačných strojoch pre drevospracujúci priemysel. Zvolen: Technická univerzita vo Zvolene. Fakulta environmentálnej a výrobnej techniky, $79 \mathrm{p}$.

Balog, J., Chovanec, A., \& Kianicová, M. (2002). Technická diagnostika, Vydala Trenčianska univerzita Alexandra Dubčeka v Trenčíne v spolupráci s VOP 027 š.p. Trenčín a vydavatel'stvom GC Tech, $115 \mathrm{p}$.

Dálik, P. (2011). Diagnostika hydraulických olejov. In Tribotechnika, (pp. 18-19). Žilina: Vydavatel'stvo TechPark, o.z., 2011, ročník IV, číslo 4.

Day, M., \& Bauer, Ch. (2007). Water Contamination in Hydraulic and Lube Systems. In Practicing Oil Anlysis. [online databáza]. Court, Tulsa: NORIA Corporation, September 2007. [cit. 10. augusta 2018]. Retrieved from: <http://www.machinerylubrication.com/Re$\mathrm{ad} / 1084$ /water-contamination-lube>

Hnilica, R., \& Dado, M. (2012). Basic mechanisms of metalworking fluid mist formation. Použitie ekologicky vhodných médii v hydraulických a mazacich systémoch lesných strojov: Kolokvium ku grantovej úlohe, (pp. 56-60). Zvolen: Technická univerzita vo Zvolene. VEGA 1/0525/09. CCC, WOS, SCOPUS.

Hnilicová, M., \& Kučera, M. (2013). Tribotechnická diagnostika hydraulických olejov v laboratórnych a prevádzkových podmienkach. In Acta facultatis technicae: vedecký časopis Fakulty environmentálnej a výrobnej techniky, (pp. 65-76). Zvolen: Technická univerzita vo Zvolene., roč. 18 , č. 1 .

Hybská, H., Knapcová, I., Fialová, J., \& Veverková, D. (2018). Testing toxicity of water contaminated by oils. In Waste forum: electronic peer-reviewed journal on all topics of industrial and municipal ecology, (pp. 190-197). URL: http:/www.wasteforum.cz/cisla/WF 2 2018.pdf\#page=98. APVV-16-0326; VEGA 1/0377/17. SCOPUS

Hybská, H., Vel'ková, V., Samešová, D., Fialová, J., \& Kučera, M. (2017). Study of the regeneration cleaning of used mineral oils ecotoxicological properties and biodegradation. In Chemical and biochemical engineering quarterly, (pp. 487-496). VEGA 1/0826/15; VEGA 1/0377/17. CCC, WOS, SCOPUS.

Ilčí, Š., Štollmann, V., \& Šmal, P. (2011). Technologická úprava olejov na Technickej univerzite vo Zvolene. In TriboTechnika, (pp. 30-32). Žilina: Vydavatel'stvo TechPark, o.z., ročník IV, číslo 2.

Krilek, J., \& Dobrotová, L., 2016, Preventívna údržba hydraulických žeriavov pomocou analýzy hydraulických olejov. Acta facultatis technicae: vedecký časopis Fakulty environmentálnej a výrobnej techniky, 21(1), 41-53. Zvolen: Technická univerzita vo Zvolene.

Krilek, J., Kováč, J., Kučera, M., \& Dobrotová, L. (2016). The hydraulic oil analysis of for determination of the number of mechanical dirt and water content in hydraulic cranes. In Hidro-ta pnevmopryvody mašyn sučasni dosiahnenňa ta zastosuvanňa: II Mižnarodna naukovo-technična konferencija, (pp. 86-89). Vinnycia: T. P. Baranovska.VEGA 1/0826/15.

Kučera, M. (2000). Verträglichkeit von Dichtungsmaterialien den hydraulischen Elementen der Forstmachinen mit biolisch leicht Abbaubaren Hydraulikölen auf Rapsölbasis. In Forest and wood technology vs. environment: proceedings of the international scientific conference Mendel University of Agriculture and Forest Brno, 
(pp. 197-202). Brno: Mendel University of Agriculture and Forestry.

Kučera, M. (2003). Biologicky rýchlorozložitel'né hydraulické oleje v hydrostatických systémoch lesných strojov. In Acta Facultatis Technicae, (pp. 43-49).

Nováček, Vladimír. (2010). Jak sledovat znečistěni průmyslových olejü. In Tribotechnické informace, (pp. 18-20). Praha: Technický týdeník, číslo 2. [cit. 11.11.2016]. Retrieved from: <http://www.tribotechnika.cz/images/casopis/2010-2.pdfs.
Parker, Hannifin. (2011). Icount Oil Sampler. [online]. [cit. 11.11.2016]. Retrieved from: <http://www.parker.com/literature/Hydraulic\%20Filter/ConMon/icount\%20Oil\%20Sampler.pdf $\$$.

Parker, Hannifin. (2015). Př́ručka filtrační techniky, FDHB289 CZ. Parker Hannifin, s.r.o., 38 p.

Štollmann, V. (2010). Nezabúdajme na hydraulické systémy. In TriboTechnika, (pp. 24-26). Žilina: Vydavat. TechPark, o.z., ročník III, číslo 3.

\section{Йозеф Крілек ${ }^{1}$, Ян Ковач1, Томаш Кувік', Люція Добротова ${ }^{2}$ \\ ${ }^{1}$ Технічний університет Зволена, м. Зволен, Словачька республіка ${ }^{2}$ BRC Slovakia, TзОВ, м. Зволен, Словацька республіка}

\section{АНАЛІЗ ГІДРАВЛІЧНОЇ РІДИНИ ПРИВОДУ СТРІЧКОВОЇ ПИЛКИ}

Транспортування та перероблення матеріалів - це частина технологічних процесів деревообробної промисловості, у яких часто використовують гідропривід. Контроль забруднення полягає у запобіганні потраплянню забруднювальних речовин у гідравлічну систему, розміщення фільтрів у стратегічних місцях гідросистеми так, щоб захопити всі частки бруду, які потрапляють у рідину. Для сучасних пристроїв успішна програма контролю забруднення повинна також включати регулярну оцінку чистоти гідравлічної рідини. Часто це потрібно робити кожні два-шість місяців, або кожні 500 або 1000 год роботи залежно від робочого циклу пристрою, робочого середовища тощо. Для збільшення терміну служби гідравлічних приводів, гідравлічні рідини повинні відповідати індивідуальним фізичним характеристикам. Для забезпечення надійності необхідна своєчасна діагностика таких рідин. Фахівці рекомендують тестувати оливу відразу після кожного випадку контакту гідросистеми із зовнішнім середовищем: поповнення гідрорідини, присадок й ін. Розглянуто методологію вимірювання основних фізичних властивостей гідравлічних олив діагностичним устаткованням безпосередньо на гідравлічному приводі стрічкової пилки під час її експлуатації. Така методологія дає змогу приймати рішення для поліпшення стану гідравлічної рідини.

Ключові слова: гідравлічна олива; діагностика; безвідмовна робота; стрічкова пилка. 